J. Clin. Chem. Clin. Biochem.

Vol. 25, 1987, pp. 499-503

(C) 1987 Walter de Gruyter \& Co. Berlin - New York

\title{
Diagnostic Value of Low-Molecular Mass Proteins in Serum for the Detection of Reduced Glomerular Filtration Rate
}

\author{
By $K$. Jung
}

Abteilung für experimentelle Organtransplantation

B.-D. Schulze

Klinik für Innere Medizin

Karin Sydow

Klinik für Nuklearmedizin, Bereich Medizin (Charité) der Humboldt-Universität zu Berlin, Berlin, DDR

Monika Pergande

Abteilung für experimentelle Organtransplantation

K. Precht

Klinik für Innere Medizin

and

G. Schreiber

Zentrallaboratorium des Städtischen Krankenhauses im Friedrichshain, Berlin, DDR

(Received February 26, 1987)

Summary: The diagnostic value of the low-molecular mass proteins ribonuclease, $\beta_{2}$-microglobulin, and lysozyme in serum for the detection of reduced glomerular filtration rates was evaluated. The values of these proteins and of serum creatinine investigated in 52 patients suffering from chronic renal diseases were plotted against ${ }^{99}$ m-Tc-diethylenetriaminopentaacetate clearance as an indicator of glomerular filtration rate. Logtransformed data showed a good fit of linearity. Considering the $95 \%$ confidence limits of the regression equations, ribonuclease increased above the normal range when the glomerular filtration rate was lower than $1.24 \mathrm{ml} / \mathrm{s}$ whereas the other analytes partly remained within their normal limits. Out of those 18 patients with glomerular filtration rates lower than $1.24 \mathrm{ml} / \mathrm{s}$, all patients showed elevated ribonuclease levels. $\beta_{2}$ Microglobulin, creatinine, and lysozyme were increased in 17, 14, and 12 cases, respectively. Ribonuclease and $\beta_{2}$-microglobulin showed similar results when other diagnostic criteria (specificity, efficiency and predictive values) were taken into account. We recommend ribonuclease determination in serum for the detection of reduced glomerular filtration rate in the normal range of creatinine. The test is diagnostically powerful, cheap and easy to perform. 


\section{Introduction}

In recent years, interest has been shown in the diagnostic power of low-molecular mass proteins in serum and urine for the measurement of renal function (16). $\beta_{2}$-Microglobulin $(1-3), \alpha_{1}$-microglobulin $(2,3)$, retinol-binding protein $(4,5)$, lysozyme $(6)$, and ribonuclease (7) have been considered to be useful in this respect. These proteins are freely filtered through the capillary wall, then reabsorbed and catabolized in the proximal tubule cells (8). Thus, if the glomerular filtration rate (GFR) in the kidney is reduced, the concentrations of these proteins in serum increase and may be taken as suitable indicators of GFR. To evaluate their diagnostic usefulness, we have compared the behaviour of ribonuclease, $\beta_{2}$-microglobulin and lysozyme in relation to creatinine and the isotope clearance of ${ }^{99} \mathrm{~m}$ Tc-diethylenetriaminopentaacetate (DTPA), which provides a good estimation of GFR.

\section{Materials and Methods}

\section{Reagents and apparatus}

Micrococcus lysodeikticus was obtained from Ferak, West Berlin; polycytidylic acid from Boehringer Mannheim $\mathrm{GmbH}$, Mannheim (FRG); imidazole from Fluka, Buchs (Switzerland); crystalline egg-white lysozyme from Worthington Biochem. Corp., Freehold (USA); and Phadezym $\beta_{2}$-microtest from Pharmacia Fine Chemicals AB, Uppsala (Sweden). Other fine chemicals of analytical grade were from E. Merck, Darmstadt (FRG). ${ }^{99 m}$ Tc-DTPA was supplied by Isocommerz GmbH, Berlin (GDR).

We used $1001 \mathrm{M}$ and ACP 5040 Eppendorf photometers and pipettes (Eppendorf Gerätebau, Netheler \& Hinz, Hamburg, FRG), spectrophotometer DU-8 (Beckman Inc., Fullerton, CA, USA), and a refrigerated centrifuge (Model K23; VEB Zentrifugenbau, Leipzig, DDR).

\section{Procedures}

Lysozyme was measured by an improved turbidimetric method, monitoring the decrease in absorbance at $365 \mathrm{~nm}$ during $90 \mathrm{~s}$ (9). For that purpose, equal volumes of serum samples and of a $150 \mathrm{mmol} / 1 \mathrm{NaCl}$ solution were mixed and $20 \mu \mathrm{l}$ of this mixture were added to $500 \mu$ l of substrate solution. Final concentrations in the reaction mixture were $70 \mathrm{mmol} / 1$ phosphate buffer (pH 6.2) and $250 \mathrm{mg} / 1$ Micrococcus lysodeikticus. Crystalline egg-white lysozyme was used as a standard.

To determine the catalytic activity of serum ribonuclease, we used a micromethod with polycytidylic acid as substrate, and measurement of the release of acid-soluble ultra-violet absorbing products (10). The final concentrations in the reaction mixture were $0.3 \mathrm{mmol} / \mathrm{l}$ polycytidylic acid, $200 \mathrm{mmol} / \mathrm{l}$ imidazole $/ \mathrm{HCl}$ buffer $(\mathrm{pH} \mathrm{7.0)}$, and $50 \mathrm{mmol} / \mathrm{l} \mathrm{NaCl}$. Results are expressed as kU/l. One unit is defined as the amount of enzyme which produces $1 \mu \mathrm{mol}$ of acid-soluble nucleotides per min at $37^{\circ} \mathrm{C}$.

$\beta_{2}-$ Microglobulin was measured according to the instructions of the suppliers of this test kit.

Creatinine was determined by a kinetic procedure (11)
Precision studies were performed using either suitable dilutions of serum stored at $-25^{\circ} \mathrm{C}$ (ribonuclease, lysozyme) or control materials ( $\beta_{2}$-microglobulin, creatinine). Over an investigation period of 14 days we obtained $43.9 \pm 2.9 \mathrm{kU} / \mathrm{l}(\overline{\mathrm{x}} \pm 1 \mathrm{SD})$ ribonuclease, $4.72 \pm 0.33 \mathrm{mg} / \mathrm{l}$ lysozyme, $2.72 \pm 0.31 \mathrm{mg} / \mathrm{l} \beta_{2^{-}}$ microglobulin, and $99 \pm 2.6 \mu \mathrm{mol} / \mathrm{l}$ creatinine.

Glomerular filtration rate (GFR) was calculated by single compartmental model analysis of the disappearance curve of $99 \mathrm{~m} \mathrm{Tc}$ DTPA. $20 \mathrm{MBq}$ of $99 \mathrm{~m}$ Tc-DTPA was injected into a medial antecubital vein and radioactivity was measured in blood samples taken 60,90 , and $120 \mathrm{~min}$ after injection. GFR values were corrected to the body surface area of $1.73 \mathrm{~m}^{2}$.

\section{Control group, patients, and samples}

In this study, the control group ( $n=63 ; 32$ women, 31 men; mean age 35 years) consisted of healthy blood donors and laboratory staff with normal serum creatinine concentrations. The patient group (52) consisted of 33 women and .19 men (mean age 40 years) with chronic renal diseases ( 27 with chronic pyelonephritis, 25 with chronic glomerulonephritis). In all cases, the diagnosis of glomerulonephritis was based on the histological examination of kidney biopsy material. Pyelonephritis was diagnosed by anamnestic information, usual clinical chemical analyses, and X-ray and sonographic examinations.

Blood samples were collected in the morning after an overnight fast. The serum was separated and stored at $-25^{\circ} \mathrm{C}$ until analysis, which was performed not later than three weeks after collection.

\section{Statistical evaluation}

For the statistical analysis of the results the U-test according to Mann-Whithey was used. Linear regression analysis was performed on the HP 9835-A (Hewlett Packard, Paolo Alto, USA).

\section{Results}

Table 1 comprises the data of controls and the combined data of patients. A plot of low-molecular mass protein and creatinine concentrations against DTPA clearance values resulted in a non-linear relationship. We tested possible linear transformations of values and, like others before us, found that log-transformed values produced a good fit of linearity (fig. $1 \mathrm{a}-\mathrm{d}$ ). The slopes of the ribonuclease and $\beta_{2}$-microglobulin plots are significantly higher $(p<0.05)$ than those of creatinine and lysozyme. These data prove that ribonuclease and $\beta_{2}$-microglobulin increase more strikingly than creatinine or lysozyme with a simultaneous GFFR decrease.

The regression equations permit a calculation of the corresponding DTPA values. For example, by using the 99th percentiles of the control group as upper normal limits, the GFR values listed in table 2 are obtained. As indicated by the $95 \%$ confidence limits, there is a wide scatter. 
Tab. 1. ${ }^{99 m}$ Tc-DTPA clearance and serum concentrations of ribonuclease, $\beta_{2}$-microglobulin, lysozyme, and creatinine in the controls and patients ${ }^{\mathrm{a}}$.

\begin{tabular}{lcc}
\hline & $\begin{array}{c}\text { Controls } \\
(\mathrm{n}=63)\end{array}$ & $\begin{array}{l}\text { Patients } \\
(\mathrm{n}=52)\end{array}$ \\
\hline DTPA clearance $(\mathrm{ml} / \mathrm{s})$ & $\mathrm{n.d} \cdot \mathrm{c}^{\mathrm{c}}$ & $1.57 \pm 0.73$ \\
Ribonuclease $(\mathrm{kU} / \mathrm{l})$ & $21.8 \pm 5.1$ & $49.7 \pm 58.4^{*}$ \\
$\beta_{2}$-Microglobulin $(\mathrm{mg} / \mathrm{l})$ & $1.8 \pm 0.45$ & $3.88 \pm 5.58^{*}$ \\
Lysozyme $(\mathrm{mg} / \mathrm{l})$ & $8.0 \pm 2.1$ & $15.3 \pm 11.7^{*}$ \\
Creatinine $(\mu \mathrm{mol} / \mathrm{l})$ & $81 \pm 8.3$ & $122 \pm \pm 91^{*}$ \\
\hline
\end{tabular}

a Values are given as arithmetic means $\pm \mathrm{SD}$.

b Comparisons were made between the control group and the patients with the U-test; number of persons in parentheses. Symbols: *p $<0.001$.

${ }^{c}$ n.d. = not determined; however, the arithmetic mean of DTPA clearance determined on other healthy persons $(\mathrm{n}=34)$ amounted to $2.03 \pm 0.34 \mathrm{ml} / \mathrm{s}$.
Tab. 2. Upper reference limits of ribonuclease, $\beta_{2}$-microglobulin, lysozyme, and creatinine in serum in relation to the calculated GFR values.

\begin{tabular}{lcl}
\hline & $\begin{array}{l}\text { Concen- } \\
\text { tration }^{\mathrm{a}}\end{array}$ & $\begin{array}{l}\text { Calculated GFR } \\
\text { value }(\mathrm{ml} / \mathrm{s})\end{array}$ \\
\hline Ribonuclease & $33.7 \mathrm{kU} / 1$ & $1.43(1.24-1.73)^{\mathrm{b}}$ \\
$\beta_{2}$-Microglobulin & $2.80 \mathrm{mg} / \mathrm{l}$ & $1.19(1.04-1.44)$ \\
Lysozyme & $12.9 \mathrm{mg} / \mathrm{l}$ & $1.25(1.04-1.69)$ \\
Creatinine & $106 \mu \mathrm{mol} / \mathrm{l}$ & $1.33(1.16-1.60)$ \\
\hline
\end{tabular}

a 99th percentiles of the three low-molecular mass proteins in the control group (tab. 1) were calculated according to a Gaussian distribution. These percentiles and $106 \mu \mathrm{mol} / \mathrm{l}$ of serum creatinine were considered as upper limits. The corresponding GFR values were calculated from these data, taking into account the regression equations of figures $1 \mathrm{a}-\mathrm{d}$.

b The $95 \%$ confidence limits are given in parentheses.

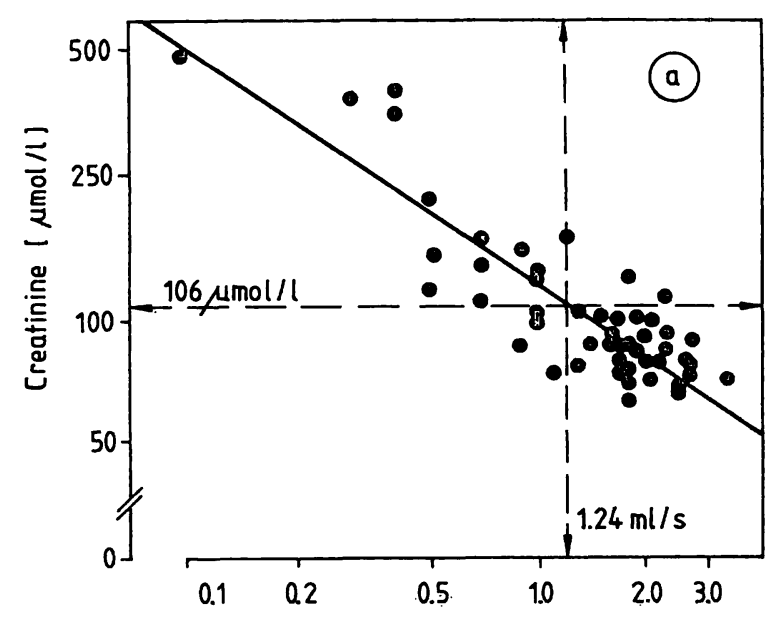

Diethylenetriaminopentaacetate clearance $[\mathrm{ml} / \mathrm{s}]$

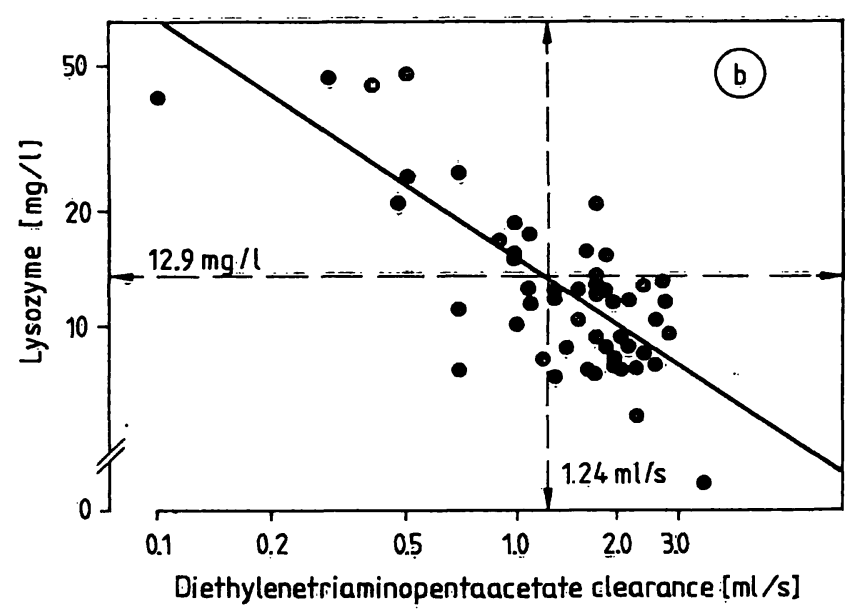

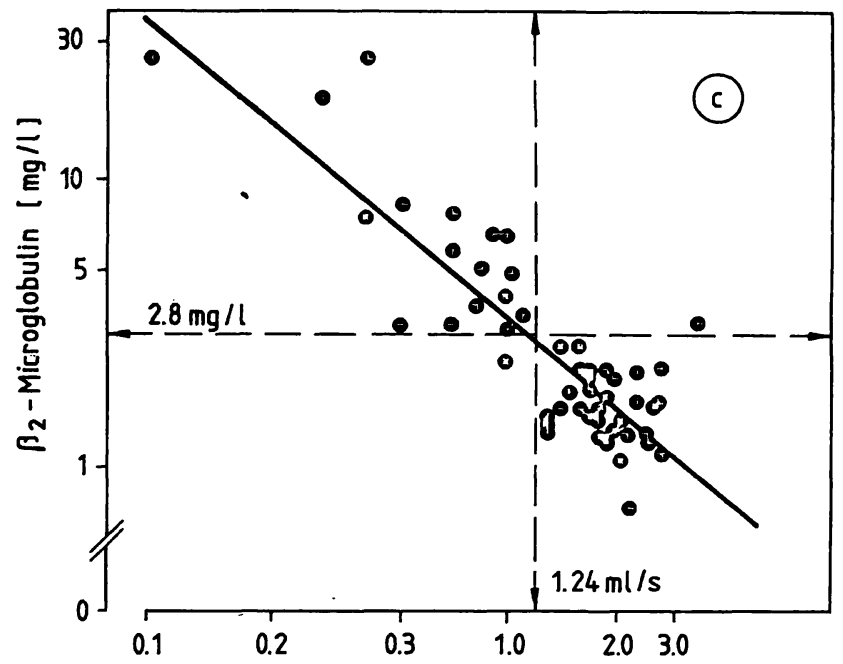

Diethylenetriaminopentaacetate clearance $[\mathrm{ml} / \mathrm{s}]$

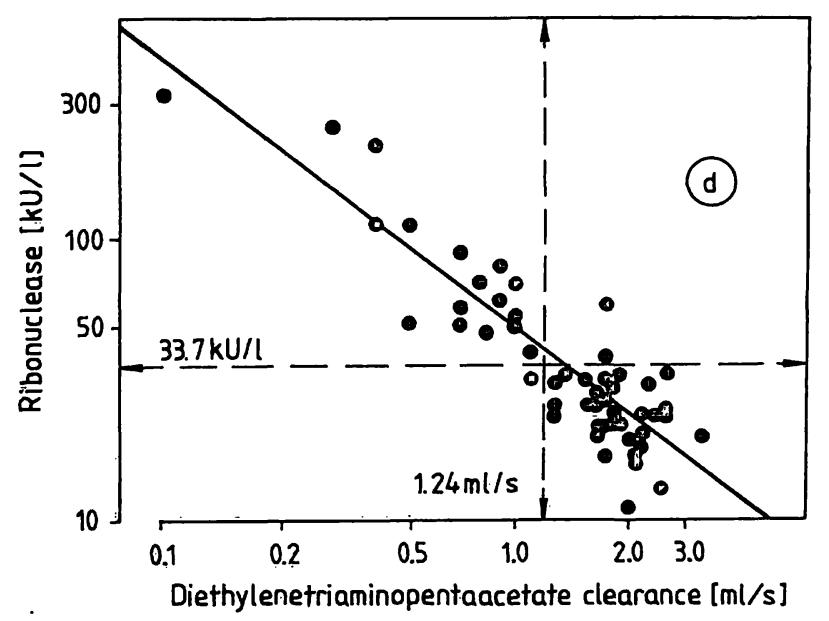

Fig. 1. Relationship of creatinine and low-molecular mass proteins in serum to ${ }^{99 m} \mathrm{Tc}$-diethylenetriaminopentaacetate clearance in 52 patients suffering from renal diseases.

$\log$ creatinine $=2.10-0.63 \log$ diethylenetriaminopentaacetate; $r=0.867$

$\log$ lysozyme $=1.17-0.63 \mathrm{log}$ diethylenetriaminopentaacetate; $r=-0.759$

$\log \beta_{2}$-microglobulin $=0.52-1.03 \mathrm{log}$ diethylenetriaminopentaacetate; $r=-0.847$

$\log$ ribonuclease $=1.68-0.96 \log$ diethylenetriaminopentaacetate; $r=0.874$.

The upper reference limits of the analytes and the lower limit of diethylenetriaminopentaacetate clearance are indicated. 
Since these comparisons hardly admit an assessment of the diagnostic evidence of the tests, we reclassified our patients by means of the measured concentrations in relation to normal values. We considered the values given in table 2 as the upper limits for the three lowmolecular mass-proteins and creatinine. Taking into account GFR values below the 1st percentile (1.24 $\mathrm{ml} / \mathrm{s}$ ) as abnormal, we found decreased values in 18 patients out of the 52 patients studied. The validity criteria of low-molecular mass proteins and creatinine in relation to DTPA-clearance are given in table 3. Ribonuclease and $\beta_{2}$-microglobulin showed comparable results.

Tab. 3. Diagnostic criteria of ribonuclease, $\beta_{2}$-microglobulin, lysozyme, and creatinine for detecting reduced glomerular filtration rate. A cut-off point of $1.24 \mathrm{ml} / \mathrm{s}$ of DTPA clearance was selected as an indicator of reduced GFR. 34 patients had higher, and 18 had lower values. For further calculation (16), the upper reference limits given in table 2 were considered.

\begin{tabular}{|c|c|c|c|c|}
\hline Criterion & $\begin{array}{l}\text { Ribonu- } \\
\text { clease }\end{array}$ & $\begin{array}{l}\beta_{2^{-}} \\
\text {Micro- } \\
\text { globulin }\end{array}$ & $\begin{array}{l}\text { Lyso- } \\
\text { zyme }\end{array}$ & $\begin{array}{l}\text { Creati- } \\
\text { nine }\end{array}$ \\
\hline Sensitivity & 1.0 & 0.94 & 0.67 & 0.78 \\
\hline Specificity & 0.94 & 0.97 & 0.88 & 0.94 \\
\hline Efficiency & 0.96 & 0.96 & 0.81 & 0.88 \\
\hline $\begin{array}{l}\text { Predictive value, } \\
\text { positive }\end{array}$ & 0.90 & 0.94 & 0.75 & 0.88 \\
\hline $\begin{array}{l}\text { Predictive value, } \\
\text { negative }\end{array}$ & 1.00 & 0.97 & 0.83 & 0.89 \\
\hline
\end{tabular}

\section{Discussion}

Serum creatinine concentrations and endogenous creatinine clearance are the most widely accepted routine parameters for the detection of a reduced glomerular filtration rate. Both parameters, however, have a limited diagnostic validity. Serum creatinine shows no response until the GFR is reduced by approximately $40 \%$, and endogenous creatinine clearance is considered unreliable for preanalytical, analytical and biological reasons (12). On the other hand, precise methods of isotope clearance required for an accurate determination of GFR are expensive, time-consuming and not well-suited to routine determination. Reliable screening tests for predicting GFR are an absolute necessity. An essential task of nephrological research therefore is to develop non-invasive methods for this purpose.

Recently, different low-molecular mass proteins have been used to measure renal function. $\beta_{2}$-Microglobu- lin $(1-3), \alpha_{1}$-microglobulin $(2,3)$, retinol-binding protein $(4,5)$, lysozyme $(6)$ and ribonuclease (7) are considered to serve this purpose, but insufficient comparative data on their diagnostic value are available $(2,3)$. $\beta_{2}$-Microglobulin is the most frequently used low-molecular mass protein for estimating GFR. Reasons for this preference may be the well-investigated behaviour of the protein in different diseases and the availability of commercial test kits for its determination. Kusano et al. (2) and Weber et al. (3) compared the diagnostic power of $\beta_{2}$-microglobulin and $\alpha_{1}=$ microglobulin and pointed out the advantages of the latter. In our study we did not determine $\alpha_{1}$ microglobulin, but our results show that ribonuclease has special diagnostic value for the detection of a reduced GFR within the normal creatinine range. To us this protein seems to be the most sensitive parameter in this study. This can be concluded from the slopes of the regression equations and the results of reclassification of the patients. Both ribonuclease and $\boldsymbol{\beta}_{2}$-microglobulin were more sensitive than creatinine in predicting reduced GFR, whereas lysozyme is even rather worse than creatinine. These observed differences may be due to different types of protein processing in the kidney (8). The renal handling of lowmolecular mass proteins include glomerular filtration, interaction with the receptors at the peritubular side, reabsorption and intracellular catabolism. These pro= cesses are specific for particular proteins depending, among others, on their molecular size, structure, and net charge (8).

We also found increased concentrations of $\beta_{2}$-microglobulin and ribonuclease in patients with ${ }^{99 \mathrm{~m}} \mathrm{Tc}-$ DTPA values above $1.24 \mathrm{ml} / \mathrm{s}$, when this value is taken as the lower normal limit of GFR.

Two essential reasons for this discrepancy have to be taken into account: either the cut-off point of ${ }^{99 m}$ Tc-DTPA was unfavourably chosen in comparison with those of the two proteins, or low-molecular mass proteins were increased by other diseases in these patients. E.g., ribonuclease was found to be increased in patients suffering from malignant neoplasms and pancreatic disease $(13,14)$. $\beta_{i}$-Microglobulin showed elevated concentrations in patients with chronic liver diseases (15). . However, since we excluded these "unspecific" reasons for increased ribonuclease in our patients, we believe that ribonuclease may serve as a suitable indicator of a reduced GFR. However, the large scatter of the GFR confidence limits which correspond to the upper limit of ribonuclease (and the other parameters) prove that these values are not suitable for the prediction of an acceptable manner. 
We therefore recommend the determination of the catalytic activity concentration of ribonuclease as a screening test for detecting reduced glomerular filtration rate in patients suffering from renal diseases but showing normal creatinine values. If more precise information about GFR is needed for patients with increased ribonuclease values, an isotope method, such as ${ }^{99 \mathrm{~m}} \mathrm{Tc}$-DTPA clearance, should be applied. We prefer the determination of ribonuclease, because this test (which gives diagnostic results similar to those obtained for $\beta_{2}$-microglobulin) is cheaper and easier

\section{References}

1. Van Eps, L. W. S. \& Schardijn, G. H. C. (1983) $\beta_{2}$-Microglobulin and the renal tubule. In: Non-invasive diagnosis of kidney diseases (Lubec, G., ed.). S. Karger, Basel, pp. $103-143$.

2. Kusano, E., Suzuki, M., Asano, Y., Itoh, Y., Takagi, K. \& Kawai, T. (1985) Nephron 41, 320-324.

3. Weber, M. H., Scholz, P., Stibbe, W. \& Scheler, F. (1985) Klin. Wochenschr. 63, 711-717.

4. Bernard, A. M. \& Lauwerys, R. R. (1981) Clin. Chem. 27, $1781-1782$.

5. Topping, M. D., Forster, H. W., Dolman, C., Luczynska, C. M. \& Bernard, A. M. (1986) Clin. Chem. 32, 18631866.

6. Shima, K., Hirota, M., Fukuda, M. \& Tanaka, A. (1986) Clin. Chem. 32, 1818-1822.

7. Reddi, K. K. (1978) Clin. Biochem. 11, 133-134. to perform than the $\beta_{2}$-microglobulin assay. Reagents for one test cost about 15 cents compared with about 2 dollars for one determination of $\beta_{2}$-microglobulin. One person can perform 100 to 200 determinations per day.

\section{Acknowledgements}

We gratefully thank Dr. K. D. Grützmann and Mrs. R. Schirrow for help in statistical calculations.
8. Maack, T., Johnson, V., Kau, S. T., Figueiredo, J. \& Sigulem, D. (1979) Kidney Int. 16, 251-270.

9. Diego, J. \& Jung, K. (1982) Z. Med. Labor-Diagn. 23, 13-19.

10. Jung, K. (1986) this J. 24, 243-250

11. Bartels, H., Böhmer, M. \& Heierli, C. (1973) Clin. Chim. Acta 37, 193-197.

12. Payne, R. B. (1986) Ann. Clin. Biochem. 23, 243-250.

13. Akagi, K., Tsuji, H., Kajiwara, E., Murai, K. \& Shikata, T. (1983) Clin. Chim. Acta 135, 83-87.

14. Corbishley, T. P., Greenway, B., Johnson, P. J. \& Williams, R. (1982) Clin. Chim. Acta 124, 225-233.

15. Amodio, P., Gatta, A. \& Ruol, A. (1984) this J. 22, 147151.

16. Büttner, J. (1977) this J. $15,1-12$.

Dozent Dr. sc. K. Jung

Abteilung für experimentelle

Organtransplantation

Bereich Medizin (Charité)

der Humboldt-Universität zu Berlin

Leninallee 49

DDR-1017 Berlin 
